\title{
Clay Tobacco-Pipe Research and Historical Archaeology in Germany, a Difficult Relationship
}

\author{
Natascha Mehler (D)
}

Accepted: 28 August 2016/Published online: 18 May 2018

(C) The Author(s) 2018

\begin{abstract}
Clay tobacco-pipe studies played an important, yet unacknowledged, role in the formation process of historical archaeology in Germany. Systematic analyses of smoking utensils and the craftsmanship involved in making them were the forerunners of the academic discipline. Clay-pipe studies were never restricted by disciplinary boundaries. Methods and approaches were drawn from ethnology, archaeology, and history, but the field remained purely Eurocentric. However, clay-pipe research has come to a halt. One important reason for this is its high degree of specialization. But, otherwise, historical archaeology is currently on the upswing, despite its unsatisfying engagement with material culture, especially that of the late 18 th century onwards. This article illustrates the development and demise of claypipe research in Germany in the context of the emergence of historical archaeology as a discipline. It includes elements in common with clay-pipe research in the United States and in Britain, and it also highlights significant differences.
\end{abstract}

Extracto Los estudios de las pipas de fumar de arcilla desempeñaron un papel importante, aunque poco reconocido, en el proceso de formación de la arqueología histórica en Alemania. Los análisis sistemáticos de los utensilios de fumar y la destreza necesaria para su fabricación fueron los precursores de

N. Mehler $(\bowtie)$

Institut für Urgeschichte und Historische Archäologie, Universität Wien, Franz-Klein-Gasse 1, A-1190 Vienna, Austria

e-mail: natascha.mehler@univie.ac.at la disciplina académica. Los estudios sobre las pipas de arcilla nunca se vieron limitados por las fronteras de la disciplina. Los métodos y enfoques se derivaron de la etnología, la arqueología y la historia, pero el campo de estudio estaba virtualmente centrado en Europa. Sin embargo, los estudios sobre las pipas de arcilla se han interrumpido por completo y un motivo importante para ello es el elevado grado de especialización. Paradójicamente, la arqueología histórica está viviendo actualmente un momento de auge, a pesar del decepcionante compromiso con la cultura material, en especial, desde finales del siglo XVIII en adelante. Este artículo ilustra el desarrollo y el declive de la investigación sobre las pipas de fumar de arcilla en Alemania, dentro del contexto de la emergencia de la arqueología histórica como disciplina. Incluye elementos en común con las investigaciones sobre pipas de arcilla llevadas a cabo en EE. UU. y Reino Unido, además de destacar importantes diferencias.

Résumé L'étude des pipes à tabac en argile a joué un rôle important, quoique non reconnu, dans le processus de formation de l'archéologie historique en Allemagne. Les analyses systématiques d'articles du tabagisme et le savoir-faire impliqué dans leur fabrication furent les précurseurs de la discipline académique. L'étude des pipes en argile n'a jamais été restreinte par des limites disciplinaires. Ses méthodes et approches se sont inspirées de l'ethnologie, l'archéologie et l'histoire, mais le domaine est demeuré purement eurocentrique. Les recherches sur les pipes en argile en sont toutefois à un point mort. Une des principales raisons est qu'il s'agit d'un champ de recherche hautement spécialisé. 
L'archéologie historique est autrement en train de remonter la pente malgré son engagement insatisfaisant avec la culture matérielle, surtout celle de la fin du $18 \mathrm{e}$ siècle et des années subséquentes. Le présent article illustre le développement et l'effondrement de la recherche sur les pipes en argile en Allemagne dans le contexte de l'émergence de l'archéologie historique en tant que discipline. Il inclut des éléments de recherche courants aux États-Unis et en Angleterre, tout en faisant la lumière sur des différences d'importance.

Keywords clay tobacco pipes · historical archaeology · Germany $\cdot$ material culture $\cdot$ academia

\section{Introduction}

In Germany, investigating clay tobacco pipes has never been easy. Far too often clay-pipe fragments were considered worthless and discarded after excavation, and even those that were kept disappeared into storage facilities at heritage agencies and museums. To this day, clay tobacco pipes divide most German archaeologists into two warring camps. One group moans whenever shown them, since they date from a time from which, it would seem, the number and variety of remains present archaeologists with insuperable problems. The other group, however, finds each and every discovery most felicitous, since they document the consumption of a new and exotic product and, indeed, provide welcome and useful evidence for dating associated finds or structures.

In U.S. historical archaeology clay tobacco pipes were among the first artifacts studied in detail when the discipline was just finding its sea legs, and claypipe assemblages from sites such as Jamestown or Williamsburg - imported from Britain to the overseas colonies - were embraced as essential objects, important not only for the dating of associated features and artifacts, but also for the understanding of colonial contacts and the diffusion of smoking; e.g., Harrington (1954) and Nöel Hume (1970:296-313). American research at that time was closely linked and, in part, also based on the work of British colleagues who had initiated research on clay tobacco pipes and who had laid the foundations of the field by establishing initial typologies and useful dating frameworks, e.g., Oswald (1951, 1960). Since then, clay tobacco-pipe analysis is an unquestioned part of all post-excavation work, and knowledge of imports, native clay-pipe production, and consumption patterns has increased significantly (Rafferty and Mann 2005; Agbe-Davis 2010:70-76; Fox 2015).

In Germany, too, clay tobacco pipes played an important, but hitherto unappreciated, role in the formation of the discipline. Clay-pipe research started in the late 1980 s, roughly at the same time when interest in postmedieval archaeology first began. However, the academic study of clay tobacco pipes - viewed within the context of the development of historical archaeology as an academic discipline- - took different turns, respectively, in Germany and the United States. Before elaborating on this, I have to point out that historical archaeology in Germany is a term that has no precise, agreed-upon meaning in scholarly discourse: sometimes it refers to the archaeology of the postmedieval period, sometimes this term also includes the archaeology of the Middle Ages, and for some it even includes any period for which written sources exist (Mehler 2013). To simplify matters, I shall use the term historical archaeology in this paper instead of postmedieval archaeology.

\section{History of Research on Clay Tobacco Pipes}

The early days of the academic study of clay tobacco pipes in Germany began in the late 1980s with the discipline that was formerly called ethnology or folklore studies, in German, Volkskunde. A small group of cultural anthropologists discovered the potential and the significance of clay tobacco pipes for the study of the history of the potter's craft. Martin Kügler (1987) laid the foundations of the field, and his pathbreaking contribution included a terminology of clay-pipe components, craft tools, and craft descriptions that would provide the basis for future systematic studies. A year later, in 1988, the German Clay-Pipes Working Group (Arbeitskreis Tonpfeifen) was founded and began to publish its own journal, Knasterkopf, in 1989 (KluttigAltmann and Mehler 2007:12). Right from the start, the aim of the journal was not only to present clay tobacco pipes as simple objects, but also to investigate the cultural history of smoking. It should be pointed out that porcelain tobacco pipes (which strictly speaking are also clay tobacco pipes) remained the domain of art historians; e.g., Morgenroth (1989) and Niehoff (1997). The early examples of porcelain pipes from the late 18 th 
century were rare luxury objects and affordable only to few (Morgenroth 1989:115-118). The ones that are preserved today are part of museum collections and, for the most part, belong to the research realm of art historians. By the late 19th century, as a consequence of industrialization, porcelain pipes had become much cheaper and turned into everyday objects for even the lowest classes of society (Heege 2010:178-179). Porcelain pipes would, thus, surely be an important part of the material culture of the time, but the archaeology of the 19th century is a neglected research field in Germany (Mehler 2015). The vicious circle is evident: the few archaeological excavations of 19thcentury structures result in a scarcity of porcelain pipes available for study, which, in turn, accounts for a lack of scholarly publications that would be available for researchers, and hence the few excavated fragments remain poorly understood.

In its peak years in the 1990s, the Clay-Pipes Working Group had about 300 members in Germany, with a few individuals in Austria, Switzerland, the Netherlands, and Great Britain. The early volumes were thin booklets and generally contained only a handful of papers, most of them written by the core members of the group. The 2001 volume of Knasterkopf marked a new era of academic scholarship (Fig. 1). Invited papers were in the forefront, and, as specific authors were asked to present their research, the format and layout of the journal were changed and the quality of editing improved. The systematic study of clay pipes across Europe was now encouraged and supported. Milestones included the publication of a thematic volume on clay tobacco pipes from the Baltic region, e.g., Reinfelde (2005), the provision of extensive clay-pipe terminologies in German, English, Dutch, French, Czech, Hungarian, and Polish, as well as standardized guidelines for drawing and documenting clay pipes. ${ }^{1}$ The first 17 volumes of the journal are characterized by articles that presented clay tobacco-pipe assemblages from individual sites and identified workshops from various locations and/or clay-pipe makers by name and date. Indeed, articles were often accompanied by detailed gazetteers (catalogs with detailed descriptions and photographs or drawings). Largely descriptive as these papers were, they form the basis of what is known today about clay pipes and their production in Germany. They also

\footnotetext{
${ }^{1}$ The terminologies are available online at $<\mathrm{http} / /$ helene-bonn .info/AK/term_int.htm>.
}

provide the foundations for research on a distinct group of artifacts that previously had not been analyzed in Germany. Furthermore, contextualized interpretations can be essayed only if the basics are mapped out.

Despite this focus, clay pipes were never mere objects; they were studied in the context of their use and function, the social class of the former owner, the smoking history of the time period, and the economic implications of the pipe-making craft and trade. For example, a study by Rüdiger Articus (2004), based on written sources and pictorial evidence, investigated the role tobacco and smoking played in the lives of women. His research showed that smoking was not limited to men, but was part of the everyday life of women of all social classes. Ruud Stam (2001) and Richard Gartley (2003) demonstrated how clay pipes were instruments for expressing political views as early as the 17 th century, and that this was a phenomenon characteristic of countries such as France, England, the Netherlands, and the United States. Another study, based on written sources of the 18th and 19th centuries, focused on the pipe-maker's craft in the Westerwald area and included typological analyses of the pipes, workshop tools, and kilns, as well as historical photographs and interviews with the last German clay-pipe producers operating (Kügler 1995:25-29). The early inclusion of the cultural practices of smoking and the social context of both producers and owners can be seen as a distinctive characteristic of German clay-pipe research. In the United States, in contrast, early clay-pipe studies focused more on the usefulness of clay pipes as dating tools, and an interest in interpretive approaches developed much later. German archaeologists who took up clay-pipe research also studied the many excavated fragments by analyzing fabrics; identifying clay sources by means of x-ray fluorescence spectroscopy; establishing ware types; defining classifications and typologies based on bowl forms, ornamentation, and marks; and contextualizing them based upon the layers and locations in which they were found; e.g., Kluttig-Altmann (2002), Röber (2002), Schmaedecke (2002), Heege (2003), and Mehler (2010). Their work also included an analysis of written and pictorial sources. For example, some studies based on written sources focused on the economic history of pipes, such as the analysis of the export of clay pipes produced in the Westerwald to France, Switzerland, and Italy in the early 19th century (Kügler 1996). Others focused on the late 18th- and early 19th-century clay-pipe workshops and products 


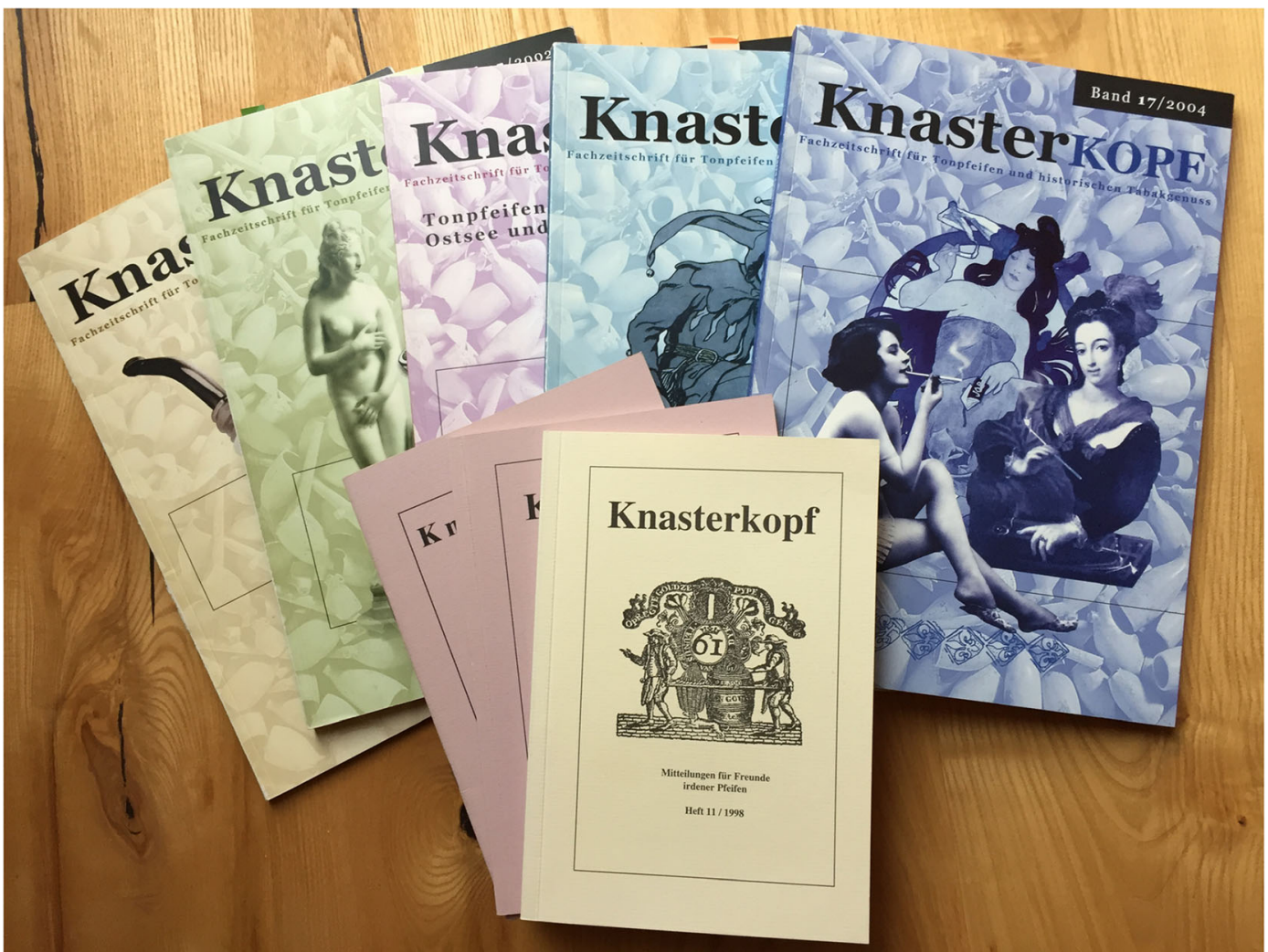

Fig. 1 Early volumes of Knasterkopf, the journal of the German Clay-Pipes Working Group (foreground) with volumes published after 2001 (background). (Photo by author, 2015.)

in Grimma, Saxony (B. Standke 1997). The cultivation of tobacco plants was also investigated, e.g., Lauerwald (1998), and a cultural-historical approach is evidenced by works on the history of smoking, e.g., Wilts (1996), and the ways in which clay pipes can reveal smuggling activities in the archaeological record (Mehler 2009:276). Hence, German clay-pipe research was never restricted by disciplinary boundaries. The founders of the working group had been folklorists (ethnologists) who approached clay pipes and the craft of pipe making using the standard methods of their discipline (Göttsch and Lehmann 2001). They were soon joined by archaeologists, historians, and art historians, who all brought their approaches and methodologies.

In 2005, Knasterkopf introduced thematic volumes with the aim of focusing on specific aspects of clay-pipe research and on the history of smoking, to better contextualize the typological and chronological results, and to initiate research on topics that had hitherto been neglected. For example, contact with other academic disciplines was encouraged, for example, with biological anthropologists to present aspects of forensic research on smoking (Meyer 2007) and geologists to investigate the geological background of clays used for the production of pipes within a certain area (G. Standke 2003). Noteworthy also is the 2007 Knasterkopf volume on clay pipes as grave goods, in which clay pipes were interpreted as expressions of individuality within a grave (Kenzler 2007) or as signs that their former user was drawn to superstition and believed that a clay pipe in the coffin would accompany the deceased safely into the afterworld. Alternatively, when found buried alongside criminals or people otherwise excluded from society, clay pipes were interpreted as having been viewed as ominous objects that embodied the evil in the dead malefactors and, consequently, were placed in their coffins in order to banish the evil from the community of the living (Mehler and Kluttig-Altmann 2007:51).

The early years of German clay-pipe research were characterized by a strong methodological approach borrowed from the neighboring Netherlands, where the field had already been established through works such as Pijpelogie (which translates as "pipe-ology") by Friederich (1975), amongst others. Here, the clay-pipe 
producers' trademarks and workshops were researched through systematic studies of the written sources at hand (Duco 1982; van der Meulen 2003). The overarching role of the Dutch clay-pipe industry in almost all parts of the world was soon recognized. For many years, Dutch clay pipes were regarded as dominating German claypipe assemblages. However, as systematic studies appeared in ever greater numbers, German clay-pipe research freed itself from the dominance of the Dutch (Kluttig-Altmann and Mehler 2007:72-73). As the number of identified workshops in Germany grew, primarily dating to the late 18 th and 19 th centuries, awareness of distinct German clay-pipe products and craft methods began to emerge. Most of the research was concentrated largely in the area of the Westerwald, a hilly region west of the Rhine (Kügler 1987, 1995), well-known as the core area of many skilled potters and the site of a highly productive stoneware industry that exported its products to all parts of the world. Research next included clay-pipe workshops and products in the states of Lower Saxony (Seeliger 1993; Heege 2003) and Hesse (Stephan 1995). Production sites of other areas, such as Saxony (Kluttig-Altmann and Kügler 2003), Baden-Württemberg (Schmaedecke 2003), and Bavaria (Mehler 2010) were also studied.

In the latter part of the 18th century and during the 19th century, German pipe makers were, to a great degree, inspired by the products of their Dutch competitors. Pipe-bowl forms and decorations were adopted, if not duplicated. Clay pipes with imperfect reproductions of the coat of arms of Gouda, the most important Dutch center of manufacture, or misspelled versions of the place name "Gouda" are generally interpreted by scholars as signs of plagiarism by German pipe makers, slavishly imitating Dutch originals (Kluttig-Altmann and Mehler 2007:72-73). Despite this dominance of the Dutch clay-pipe industry in the 19th century, distinctive clay-pipe traditions existed in some parts of Germany as early as the 17th century. For example, in Upper Lusatia (in the state of Saxony), clay pipes of the late 17 th century were produced by turning their bowls on a potter's wheel, instead of forming them in molds, and then fixing them to handmade stems (Fig. 2). Alternatively, both bowls and stems might be formed by hand, without the help of molds or a potter's wheel. Bowls and/or stems were then encircled with rolled-on decoration, such as geometrical ornament. Clay pipes of this type have so far been found only in this part of Germany, and their mode of production and their

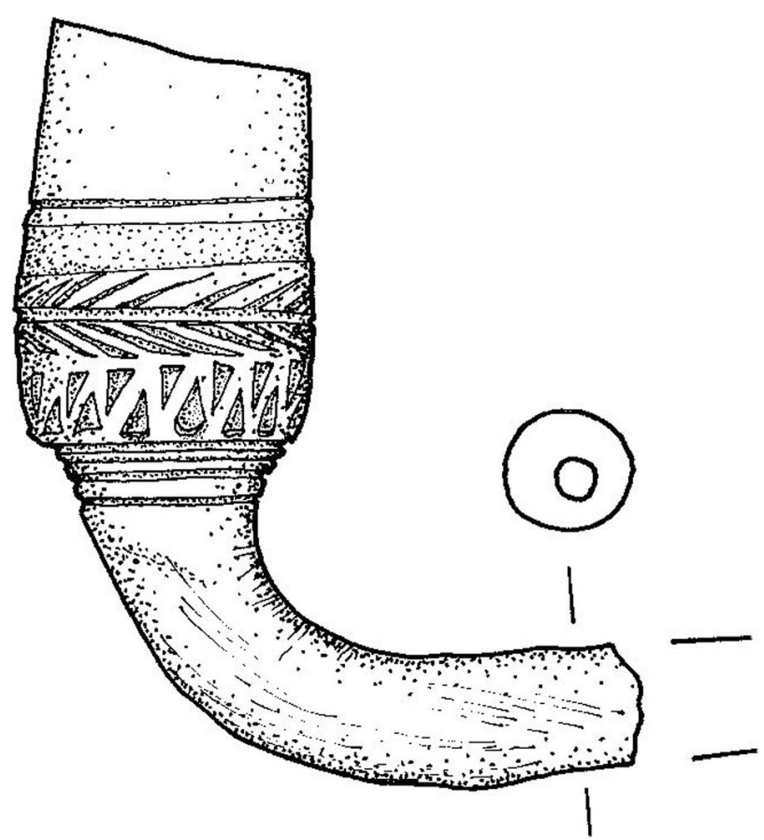

Fig. 2 Clay pipe with head produced on a potter's wheel, found in Saxony. (Drawing by Ralf Kluttig-Altmann, 2006.)

distinct shape and decoration make them unique among German clay-pipe products. The occurrence of a number of such finds within the area of Upper Lusatia and neighboring Poland suggests a similar manufacturing tradition in this region (Kluttig-Altmann and Kügler 2003; Kluttig-Altmann and Mehler 2007:74-77; Kluttig-Altmann 2013). At about the same time, Bavarians farther south preferred their clay pipes to be highly ornamented or glazed, predominantly in green, but also in blue or brown. There clay pipes were produced exclusively with the use of molds, their bowls in many cases being ornamented either with floral decoration, rosette decoration, or faces of humans or composite beings (Fig. 3). One of the most remarkable and characteristic features of Bavarian pipes from the late 17th and early 18 th centuries is that they were marked in a very distinctive way. Whereas in England and the Netherlands pipes often bear the stamped initials of their makers, Bavarian pipes bear molded letter marks that consist of the initials of the officials who held the monopoly on tobacco and clay-pipe production and trade at that time. In 1675, Elector Ferdinand Maria established the Bavarian tobacco monopoly, which was not restricted to tobacco alone, but also included the productions of and trade in smoking accessories. Pipes were marked with the monopolist's initials in order to make it clear that the pipe came from one of 
Fig. 3 Selection of 17th-century clay pipes produced and found in Bavaria, with molded letter marks and rosette decoration. (Photo by author, 2003.)



the monopolists' production centers and the owner had acquired it lawfully. Hence, Bavarian pipe marks of that time can be interpreted as tax labels, similar to those found on modern cigarette packs. The Bavarian tobacco monopoly was in effect until 1745 (Mehler 2009:267276, 2010:74-77). These examples of eastern and southeastern German clay tobacco-pipe groups show how different and independent pipe production was from that of the Netherlands during the 17th and 18th centuries.

Despite its openness to other disciplines, such as economic and sociocultural history, German clay-pipe research remained resolutely Eurocentric. Solid contacts were built up with clay-pipe researchers in the Netherlands and Great Britain, and Knasterkopf regularly included clay-pipe articles from neighboring countries. However, the global character of clay tobacco pipes was not recontextualized. The spread of smoking from the Americas to other continents had a profound cultural and economic impact on the entire globe (Goodman 1993). Tobacco and clay pipes were traded widely, not only throughout Central Europe, but also from continent to continent. For example, in the 17th and 18th centuries tobacco was imported to Bavaria from Virginia and the Caribbean (Nadler 2008:143). In the 19th century, German stub-stemmed pipes decorated with the portraits of American presidents and politicians (so-called president pipes) were produced to order in Großalmerode (Hesse) and Uslar (Lower Saxony), and in 1845 an estimated 13.5 million industrially manufactured pipes were exported to support politicians' election campaigns in the United States (Stephan 1995; Kühne 2011). These pipes can be dated to within a few years, since their popularity depended on the careers of the politicians depicted (Fig. 4). Despite such compelling evidence, clay-pipe production and the consumption of tobacco was hardly studied in a global context by linking consumer habits and production modes of different continents.

The heyday of German clay-pipe research was largely over when the Internet - a magnificent research tool and a means of boundless communication-became widely available. To some degree, this may account for the lack of engagement with the approaches,

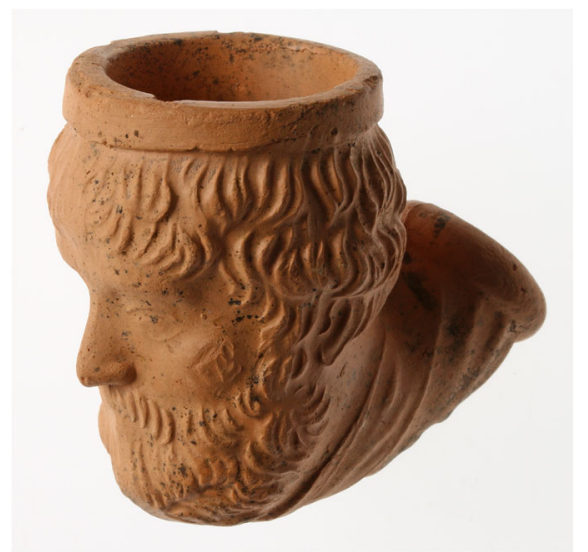

Fig. 4 Unfinished "president pipe" (unglazed) produced in Großalmerode (length $4.9 \mathrm{~cm}$, height $4.1 \mathrm{~cm}$ ). The pipe bowl depicts Ulysses S. Grant, president of the United States from 1869 to 1877 . (Photo by Rolf Kiepe, Niedersächsisches Institut für Historische Küstenforschung Wilhelmshaven, 2018.) 
methods, and literature of overseas clay-pipe research, but there may be another reason why North American and German clay-pipe scholars failed to initiate and pursue contacts. German clay-pipe research was characterized by a cultural-historical approach, which differed considerably from the anthropological approach characteristic of Northern American archaeologists, something which also becomes evident with the methods used in both places. The clay-pipe dating methods using statistical analysis of pipe-stem bore diameters - e.g., Harrington (1954) and Binford (1962) - were milestones in early American processual archaeology and are still commonly in use, though widely debated; e.g., Walker (1970:161), Deetz (1988:364-365), Monroe and Mallios (2004) and Mallios (2005). These methods were later introduced to British postmedieval archaeologists to demonstrate their value and their limitations (Walker 1967), but the attempt remained unsuccessful. Using stem-bore diameters as a dating tool has not been accepted in either Great Britain, e.g., Belcher and Jarrett (1971), or Germany.

Despite its continuing research accomplishments, the journal Knasterkopf struggled to secure permanent funding. Each volume had to be produced through voluntary work by a small group of enthusiasts. For most of the years of its existence, Knasterkopf was affiliated with the Helms-Museum in Hamburg and distributed through its offices, but contracts had to be individually negotiated for each volume. Clay pipes were - and still are - seen by many as mere curiosities, or simply objects that did nothing more than prove that smoking was not a recent invention. For the most part, clay-pipe research was never really accepted by the scientific community of German archaeologists. Institutions, such as universities or museums, that could have hosted and financed the publication of the journal were conspicuously uninterested. The constant struggle to fund each Knasterkopf issue and find an institution that would take the publication of the journal under its wing, and finally the inability to attract fresh blood, itself the result of not including clay-pipe research in university curricula, finally wore out the enthusiasm of most working-group members. Although the journal was distributed internationally and widely appreciated, the Helms-Museum in Hamburg discontinued funding, and the last Knasterkopf issue was published in 2009. The German Clay-Pipes Working Group closed down at its 25th and final annual meeting in Raeren, Belgium, in 2013 (Hermann and Kluttig-Altmann 2014). However, the
Knasterkopf Website remains online and includes summaries of each paper published since 1989, and most of the issues are still available for sale. Nevertheless, these German clay-pipe researchers laid the foundations for future artifact identification and research, and provided tools and methods for the future. They also left behind a solid corpus of useful data, clay tobacco-pipe publications, and their hopes that clay tobacco pipes would one day get the academic attention they so deserve.

\section{Historical Archaeology in Germany}

The term historical archaeology does exist in Germany, but is rarely used and, if so, only in the relatively recent and principally academically led discussion about the future development of medieval and postmedieval archaeology as an academic discipline (Frommer 2007; Müller 2012:81-85; Mehler 2013). The academic discipline of medieval and postmedieval archaeology was officially created in 1981 with the foundation of the Department of Medieval and Postmedieval Archaeology at Bamberg University in Bavaria. At that time, the intention was to have two professorships at Bamberg, one to cover the medieval period and one for the postmedieval period, but for financial reasons this never came to pass. The postmedieval chair was never founded, and, as a result, postmedieval archaeology tended to be sidelined until after 2000. In 1991, the German Society of Medieval Archaeology expanded its timeframe to include the postmedieval period and renamed itself the German Society for Medieval and Postmedieval Archaeology (Deutsche Gesellschaft für Archäologie des Mittelalters und der Neuzeit, or DGAMN). However, engagement with the archaeology of the more recent period has become noticeable only in the past 10 years (Ericsson 1995; Gaimster 2009:526537; Stephan 2012; Mehler 2013). In 2004, the only other German professorship in medieval and postmedieval archaeology was founded at the University of Halle (Saale) in Saxony-Anhalt. At Bamberg and Halle, an average of only one course in postmedieval archaeology is taught per academic year. Despite their name, these departments consequently do not differ much from the other two archaeology departments (at the Universities of Kiel and Tübingen) that frequently teach postmedieval archaeology without being so identified. Despite several attempts by specialists to encourage teaching at university departments that includes clay-pipe research, 
this has not yet happened. In general, postmedieval archaeology at German universities is in an unstable state, as teaching and research depend largely on the enthusiasm of individual scholars and the current employment situation. In spite of that, the archaeology of the postmedieval period is slowly gaining a foothold in Germany.

This academic inertia stands in stark contrast to what is practiced and experienced in the field during excavations by government agencies and private companies. Before the 1990s, postmedieval and, to some extent, medieval building remains and artifacts were largely shoveled away during the many excavations that were carried out as parts of urban development and building activities, especially during the period of reconstruction after World War II. But, since then, increasing care has been taken to document such remains also and retain artifacts of the postmedieval period. These developments, and the increased consideration of the significance of monuments and artifacts of the recent past, have certainly been a spur for the evolution of the academic discipline of historical archaeology in Germany. This parallels the input into historical archaeology that cultural resource management archaeology in the United States has had, although this happened much earlier in the U.S. Still, in Germany, the historical monuments commissions of the federal states are somewhat overwhelmed in the face of the huge amount of postmedieval material culture and structural remains, especially from the 19th and 20th centuries (Antkowiak and Meyer 2009). Hence, historical archaeology leads a double life in Germany, split between practitioners in the field and an academic discipline struggling to find itself. This problem has been recognized, and, in 2016, an expert committee for the Archaeology of the Modern Period (the 19th and 20th centuries) of the German Union of Archaeologists (Fachausschuss Archäologie der Moderne des Deutschen Verbandes für Archäologie) was founded. Its aim is to mediate the challenges that the archaeology of the recent past generates among university departments, heritage management offices, and the commercial sector, and, additionally, to provide a contact for academia, government and private practitioners, and the public.

Despite a palpable uptick in interest, it must be stressed that, compared to North America and even Great Britain, historical archaeology in Germany is still in its infancy, and the current state of research is also very different among the various federal states. In sum,
German historical archaeology is (still) largely an archaeology of the 16th and 17th centuries, and is approached as an extension of medieval archaeology (Gaimster 2009:527; Mehler 2013:18). However, the last 15 years have witnessed the inclusion of the archaeological remains of World War II and a noticeable interest in contemporary archaeology, brought about by an increase in building or restoration activities in former concentration camps, amongst others. In places such as Berlin, the remains of the Cold War are being incorporated into archaeological investigations. As a result, the main focus of study for the more recent period is on the remains of war and conflict, e.g., Theune (2016), whereas the excavation of late 18th- and 19thcentury archaeological sites and the study of the material culture of those time periods is very rare (Mehler 2015). Contemporary archaeological sites do not include clay tobacco pipes, so there is no need to engage with this material.

In Germany, clay-pipe research was practiced by professionals in different disciplines who collaborated with one another. Seen in the context of the development of historical archaeology, it is clear that the archaeological and anthropological study of clay tobacco pipes started roughly when historical archaeology began to emerge in Germany in the 1980s. However, when historical archaeology slowly began to grow in the late 1990s, it did so without really engaging with clay-pipe research, which had been very active for at least 10 years and by then had already become quite advanced. The only exception was the study of 17 th- and early 18 thcentury Bavarian clay tobacco pipes by Mehler (2010), which remains the only academic thesis on clay pipes done by a medieval and postmedieval archaeologist. Despite a growing body of literature and groundbreaking results, the study of clay pipes was never included in the curricula of archaeology departments, as material culture of that period was and still is rarely studied. German historical archaeology as a discipline would have benefitted greatly from the methods and results that had already been developed in clay-pipe research. In some parts of Germany, basic knowledge about pipe makers and their production ranges was known and could have provided archaeologists with a firm basis upon which to date other associated material. Beyond that, the approaches with which clay pipes were studied anticipated the cultural turn that has begun to emerge in German historical archaeology. By the time historical 
archaeology as a discipline placed a foot in the academic door, the heyday of clay-pipe research was over. Today, historical archaeology is practiced as though the relatively brief period of academic claypipe research never occurred.

\section{Exclusivity as a Problem of Specialization}

The publication of a highly specialized journal such as Knasterkopf is not without its problems. The German Clay-Pipes Working Group was founded with the aim of supporting and encouraging in-depth studies of clay tobacco pipes. Indeed, in the beginning, the clay pipe gained more attention in academia due to the existence of its own journal. However, in the long run, Knasterkopf turned out to be a forum for specialists, generally read only by its members, remaining largely unreferenced by archaeologists outside the working group. Clay-pipe articles aimed at a broader archaeological audience and published in moregeneral archaeological periodicals were absent, with only a couple of exceptions; e.g., Teichner (1998), Röber (2002), Kluttig-Altmann (2002), and Kühne (2011).

Similar to the German Clay-Pipes Working Group, German archaeologists, folklorists/ethnologists, and others united in the study of postmedieval ceramics regularly meet at annual gatherings of the Working Group for Ceramic Research (Arbeitskreis für Keramikforschung). This group, its members anthropologists/folklorists, archaeologists, potters, and art historians, was founded in 1968, roughly five years later than the British Post-Medieval Ceramic Research Group, which, in turn, led to the foundation of the British Society for Post-Medieval Archaeology (Mytum 2016:7). However, unlike the German Clay-Pipes Working Group that was founded by members of the Working Group for Ceramic Research (who felt the need for more independence), the ceramics group did not have its own periodical. Conference proceedings were always published as special volumes within existing museum or heritage office publication series, e.g., Lichtwark (2004). Furthermore, the ceramic group is institutionalized and affiliated with the Hetjens-Museum in Düsseldorf, which specializes in ceramics. This means that academic papers on postmedieval ceramics are available in a broad range of publications, which facilitates the recognition of that work by archaeologists outside the working group. It can be concluded that, in the long run, the decision of clay-pipe specialists to split from the ceramic working group to form their own working group led to exclusiveness, isolation, and, finally, dissolution. Having understood that now from a distant temporal perspective, a look at Great Britain is worrisome because a similar process may be occurring. The Society of Clay Pipe Research, with its own journal and newsletter, was founded in 1983. In addition, the publication series, the Archaeology of the Clay Tobacco Pipe, was established in 1979, and, as a consequence, the publication of clay-pipe research articles has decreased considerably in relevant and broader archaeological journals, such as Post-Medieval Archaeology (Beaudry and Mehler 2016:113).

\section{Conclusion}

The story of academic clay-pipe research and historical archaeology in Germany is a story of bad timing and missed opportunities. It took a long time for historical archaeology to become an established field in Germany, and, by the time it did, clay-pipe research was declining. The early years of the discipline of historical archaeology were characterized by a lack of interdisciplinary engagement with the sources, methods, and approaches of folklore studies/ethnology and anthropology (Mehler 2013:15,17-20). This was in direct contrast to clay-pipe research practiced by scholars of different cultural and historical disciplines. German historical archaeology also missed the chance to ride the cultural wave that was already well advanced in clay-pipe studies. On the other hand, the Eurocentric perspective of German claypipe studies impeded the growth of a global approach, which, by extension, would have been invigorating for the development of German historical archaeology.

With the demise of the German Clay-Pipes Working Group, systematic clay-pipe studies have ceased, and indepth studies of clay tobacco pipes and/or tobacco consumption are no longer on the academic agenda of archaeologists. The legacy of the working group remains, however, consisting of solid foundations for further research and improved methods. I am convinced 
that, one day, German historical archaeology will seize this potential and build on it.

Acknowledgments: I would like to thank Barry Gaulton, Department of Archaeology at the Memorial University of Newfoundland, who encouraged me to write this article. Ralf Kluttig-Altmann (State Office for Heritage Management and Archaeology at Halle, SaxonyAnhalt) and Andreas Heege (Zug, Switzerland) commented on an earlier draft of this manuscript, and I am grateful to them for sharing their ideas with me. Finally, I would like to thank the editor of this paper, Meta Janowitz (AECOM, Burlington, New Jersey); Paul Reckner (Wisconsin Historical Society); two more reviewers, whose comments made this article much better; and last, but not least, Richard Schaefer (Historical Perspectives, Inc.), the copy editor, for his hard work and patience. Open access funding provided by University of Vienna.

Open Access This article is distributed under the terms of the Creative Commons Attribution 4.0 International License (http:// creativecommons.org/licenses/by/4.0/), which permits unrestricted use, distribution, and reproduction in any medium, provided you give appropriate credit to the original author(s) and the source, provide a link to the Creative Commons license, and indicate if changes were made.

\section{References}

Agbe-Davis, Anna S.

2010 Social Aspects of the Tobacco Pipe Trade in Early Colonial Virginia. In Social Archaeologies of Trade and Exchange: Exploring Relationships among People, Places, and Things, A. A. Bauer and A. S. Agbe-Davis, editors, pp. 69-98. Left Coast Press, Walnut Creek, CA.

Antkowiak, Matthias, and Angelika Meyer

2009 Grundlagen und Arbeitsweisen neuzeitlicher Archäologie am Beispiel des Jugendschutzlagers Uckermark (Foundations and working methods of modern-period archaeology with the example of the Uckermark youth-protection camp). Veröffentlichungen zur Brandenburgischen Landesarchäologie 39/40:299-336.

Articus, Rüdiger

2004 "Es hat dieses artige Geschlecht mit dem Mannsvolck gleiches Recht"- Frauen und Tabak ("This kind of sex has the same right with the menfolk"- -women and tobacco). Knasterkopf 17:13-20.

Beaudry, Mary C., and Natascha Mehler

2016 The Material Culture of the Modern World. PostMedieval Archaeology 50(1):108-120.

Belcher, Jill, and Michael G. Jarrett

1971 Stem-Bore Diameters of English Clay Pipes: Some Northern Evidence. Post-Medieval Archaeology 5: 191-193.

Binford, Lewis R.

1962 New Method of Calculating Dates from Kaolin Pipe Stem Samples. South-Eastern Archaeological Conference Newsletter 9(1):19-21.
Deetz, James

1988 American Historical Archeology: Methods and Results. Science 239(4838):362-367.

Duco, Don H.

1982 Merken van Goudse pijpenmakers 1660-1940 (Marks of Gouda pipe makers 1660-1940). Tijdstroom, Lochem, the Netherlands.

Ericsson, Ingolf

1995 Archäologie der Neuzeit: Ziele und Abgrenzung einer jungen Disziplin der archäologischen Wissenschaft (Archaeology of the modern period: Aims and delimitation of a young discipline of archaeological science). Ausgrabungen und Funde 40: 7-13.

Fox, Georgia L.

2015 The Archaeology of Smoking and Tobacco. University Press of Florida, Gainesville.

Friederich, F. H. W.

1975 Pijpelogie: Vorm, versiering en datering van de hollandse kleipijp (Pipe-ology: Form, decoration and dating of the Dutch clay pipe). Amor Vincit Omnia, Westzaan, the Netherlands.

Frommer, Sören

2007 Historische Archäologie: Ein Versuch der methodologischen Grundlegung der Archäologie als Geschichtswissenschaft (Historical archaeology: An attempt at the methodological foundation of archaeology as a historical science). Verlag Dr. Faustus, Büchenbach, Germany.

Gaimster, David

2009 An Embarrassment of Riches? Post-Medieval Archaeology in Northern and Central Europe. In International Handbook of Historical Archaeology, Teresita Majewski and David Gaimster, editors, pp. 525-549. Springer, New York, NY.

Gartley, Richard

2003 Deutsche "Stummelpfeifen" von Ausgrabungen in den USA (German "stub pipes" from excavations in the U.S.A.). Knasterkopf 16:180-190.

Goodman, Jordan

1993 Tobacco in History: The Cultures of Dependence. Routledge, New York, NY.

Göttsch, Silke, and Albrecht Lehmann (editors)

2001 Methoden der Volkskunde: Positionen, Quellen, Arbeitsweisen der Europäischen Ethnologie (Folklore methods: Positions, sources, working methods of European ethnology). Reimer, Berlin, Germany.

Harrington, Jean C.

1954 Dating Stem Fragments of 17th and 18th Century Clay Tobacco Pipes. Quarterly Bulletin of the Archeological Society of Virginia 9(1):9-13.

Heege, Andreas

2003 Tonpfeifen aus Einbeck, Niedersachsen (Clay pipes from Einbeck, Lower Saxony). Knasterkopf 16:1168.

Heege, Andreas

2010 Adelsburg, Hochwacht, Kuranstalt-Forschungen zur materiellen Kultur (Adelsburg, Hochwacht, Kuranstaltmaterial culture research). Kantonsarchäologie Schaffhausen, Schaffhausen, Switzerland. 
Hermann, Michaela, and Ralf Kluttig-Altmann

2014 Bericht über die 25. Tagung des Arbeitskreises Tonpfeifen vom 25. bis 27. April 2013 in Raeren (Belgien) (Report on the 25th session of the ClayPipes Working Group from 25 to 27 April 2013 in Raeren [Belgium]). Historische Archäologie. Historische Archäologie <https://www.histarch.uni-kiel .de/Artikel2014.htm>. Accessed 25 April 2018.

Kenzler, Hauke

2007 Tabakspfeifen als Grabbeigaben: Neuzeitliche Bestattungsbräuche auf dem Friedhof von Breunsdorf, Lkr. Leipziger Land (Tobacco pipes as grave offerings: Modern funerary customs in the cemetery of Breunsdorf, Leipziger Land district). Knasterkopf 19:16-28.

Kluttig-Altmann, Ralf

2002 "Hirdurch zihet man den rauch ins Maull": Tonpfeifen aus Leipziger Stadtkerngrabungen 1992-2000 im Kontext ihrer typologischen und kulturhistorischen Entwicklung ("Through this one pulls smoke into his maw": Clay pipes from Leipzig city-core excavations 1992-2000 in the context of their typological and cultural-historical development). Arbeits- und Forschungsberichte zur Sächsichen Bodendenkmalpflege 44:239-263.

Kluttig-Altmann, Ralf

2013 New Technologies in the Manufacture of Clay Tobacco Pipes in Central Europe. In Historical Archaeology in Central Europe, Natascha Mehler, editor, pp. 295-303. Society for Historical Archaeology, Special Publication No. 10. Rockville, MD.

Kluttig-Altmann, Ralf, and Martin Kügler

2003 Bewegung in Sachsen: Ein Beitrag zur Emanzipation der deutschen Tonpfeifenforschung (Movement in Saxony: A contribution to the emancipation of German clay-pipe research). Knasterkopf 16:88-98.

Kluttig-Altmann, Ralf, and Natascha Mehler

2007 Die Emanzipation der deutschen Tonpfeifenforschung (The emancipation of German clay-pipe research). Mitteilungen der Deutschen Gesellschaft für Archäologie des Mittelalters und der Neuzeit 18:71-80.

Kügler, Martin

1987 Tonpfeifen: Ein Beitrag zur Geschichte der Tonpfeifenbäckerei in Deutschland (Clay pipes: A contribution to the history of clay-pipe makers in Germany). Verlag Hanusch \& Ecker, Höhr-Grenzhausen, Germany.

Kügler, Martin

1995 Pfeifenbäckerei im Westerwald: Die Geschichte der Pfeifenbäckerei des unteren Westerwaldes von den Anfängen um 1700 bis heute (Pipe makers in the Westerwald: The history of pipe makers of the lower Westerwald from the beginning ca. 1700 until today). Rheinland-Verlag, Volkskundliche Untersuchungen im Rheinland 22. Cologne, Germany.

Kügler, Martin

1996 Der Handel mit Westerwälder Tonpfeifen nach Süddeutschland, Frankreich, der Schweiz und Norditalien zu Beginn des 19. Jahrhunderts (The trade in Westerwald clay pipes to south Germany, France, Switzerland, and north Italy at the beginning of the 19th century). Knasterkopf 8:61-80
Kühne, Christoph

2011 Uslar, Großalmerode oder Westerwald? Neue Gesteckpfeifenfunde aus Virginia/USA (Uslar, Großalmerode or Westerwald? New stub-stemmed pipe finds from Virginia/USA). Südniedersachsen Zeitschrift für Regionale Forschung und Heimatpflege 39(3\&4):89-97.

Lauerwald, Paul

1998 Der Tabakanbau auf dem Eichsfeld (Tobacco cultivation in Eichsfeld). Knasterkopf 11:13-25.

Lichtwark, Friederike (editor)

2004 Keramik auf Sonderwegen: Internationales HafnereiSymposion 37, Herne, 19. bis 25. September 2004 (Ceramics on special paths: International Ceramics Symposium 37, Herne, 19 to 25 September 2004). Verlag von Zabern, Denkmalpflege und Forschung in Westfalen 44. Mainz, Germany.

Mallios, Seth

2005 Back to the Bowl: Using English Tobacco Pipebowls to Calculate Mean Site-Occupation Dates. Historical Archaeology 39(2):89-104.

Mehler, Natascha

2009 The Archaeology of Mercantilism: Clay Tobacco Pipes in Bavaria and Their Contribution to an Economic System. Post-Medieval Archaeology 43(2):261-281.

Mehler, Natascha

2010 Tonpfeifen in Bayern (ca. 1600-1745) (Clay pipes in Bavaria [ca. 1600-1745]). Habelt Verlag, Zeitschrift für Archäologie des Mittelalters, Beiheft 22. Bonn, Germany.

Mehler, Natascha

2013 Breaking New Ground: Historical Archaeology in Central Europe. In Historical Archaeology in Central Europe, Natascha Mehler, editor, pp. 1131. Society for Historical Archaeology, Special Publication No. 10. Rockville, MD.

Mehler, Natascha

2015 Die Archäologie des 19. und 20. Jahrhunderts: Zwischen Akzeptanz und Relevanz (The archaeology of the 19th and 20th centuries: Between acceptance and relevance). Mitteilungen der Deutschen Gesellschaft für Archäologie des Mittelalters und der Neuzeit 28: 23-28.

Mehler, Natascha, and Ralf Kluttig-Altmann

2007 Tonpfeifen als neuzeitliche Grabbeigabe: Überlegungen zu den Ursachen einer Beigabensitte (Clay pipes as modern-period grave goods: Thoughts about the reasons for deposition of such grave goods). Knasterkopf 19:50-52.

Meyer, Christian

2007 Rauchzeichen am Skelett-über den anthropologischen Nachweis von Tabakkonsum in der Vergangenheit (Signs of smoke on the skeletonon the anthropological evidence of tobbaco use in the past). Knasterkopf 19:37-40.

Monroe, J. Cameron, and Seth W. Mallios

2004 A Seventeenth-Century Colonial Cottage Industry: New Evidence and a Dating Formula for Colono Tobacco Pipes in the Chesapeake. Historical Archaeology 38(2):68-82. 
Morgenroth, Walter

1989 Tabakpfeifen sammeln-Kunstwerke in Porzellan: Ein Beitrag zur Geschichte des Rauchens (Tobaccopipe collecting - artwork in porcelain: A contribution to the history of smoking). Laterna Magica, Munich, Germany.

Müller, Ulrich

2012 Die Archäologie des Mittelalters und der Neuzeit im Gefüge der historischen Archäologien (The archaeology of the Middle Ages and the modern period in the structure of historical archaeologies). In Die Aktualität der Vormoderne. Epochenentwürfe zwischen Alterität und Kontinuität, Klaus Ridder and Steffen Patzold, editors, pp. 61-91. Akademie Verlag, Berlin, Germany.

Mytum, Harold

2016 A Short History of the Society of Post-Medieval Archaeology. Post-Medieval Archaeology 50(1):618.

Nadler, Martin

2008 Der besteuerte Genuss: Tabak und Finanzpolitik in Bayern 1669-1802 (The taxed indulgence: Tobacco and financial politics in Bavaria 1669-1802). Herbert Utz Verlag, Munich, Germany.

Niehoff, Franz

1997 Porzellanpfeifen: Bilder der Lebenswelten der Studenten in Landshut und München im 19. Jahrhundert (Porcelain pipes: Pictures of the world of the students in Landshut and Munich in the 19th century). Isar-Post, Landshut, Germany.

Nöel Hume, Ivor

1970 A Guide to Artifacts of Colonial America. Alfred A. Knopf, New York, NY.

Oswald, Adrian

1951 English Clay Tobacco Pipes. Archaeological Newsletter (London) 3(10):154-159.

Oswald, Adrian

1960 The Archaeology and Economic History of English Clay Tobacco Pipes. Journal of the British Archaeological Association, 3rd ser., 23(1):40-102.

Rafferty, Sean M., and Rob Mann

2005 Smoking and Culture: The Archaeology of Tobacco Pipes in Eastern North America. University of Tennessee Press, Knoxville.

Reinfelde, Ilze

2005 Tonpfeifenfunde aus Riga: Ein erster Überblick (Clay pipe finds from Riga: A first look). Knasterkopf 18 : 51-63.

Röber, Ralph

2002 Tönerne Tabakspfeifen von der Liegenschaft Salzstraße 22 in Freiburg (Earthen tobacco pipes from the property Salzstraße 22 in Freiburg). In Das Haus "Zum roten Basler Stab" (Salzstraße 20) in Freiburg im Breisgau, F. Galioto, editor, pp. 607618. Theiss Verlag, Stuttgart, Germany.

Schmaedecke, Michael

2002 Floral verzierte Pfeifenstiele aus Südwestdeutschland und angrenzenden Regionen. Ansätze zu einer Systematisierung von Produkten vornehmlich aus dem Raum Mannheim/Frankenthal (Floral-decorated pipe stems from southwest Germany and adjacent regions. Approaches to a systematization of products mainly from the Mannheim/Frankenthal area). Knasterkopf 15:19-34.

Schmaedecke, Michael

2003 Floral verzierte Pfeifen mit Herstellerangaben aus Fundkomplexen des südlichen Oberrheins (Floraldecorated pipes with manufacturer information from assemblages of the southern upper Rhine). Knasterkopf 16:69-87.

Seeliger, Matthias

1993 Pfeifenmacher und Tonpfeifen zwischen Weser und Harzvorland: Geschichte der Handwerker und ihrer Erzeugnisse (Pipe makers and clay pipes between the Weser and Harzvorland: History of the craftsmen and their products). Verlag Schmerse, Beiträge zur Volkskunde in Niedersachsen 6. Göttingen, Germany.

Stam, Ruud

2001 Tonpfeifen und Politik: Die Bedeutung der politischen Pfeife im 19. Jahrhundert (Clay pipes and politics: The meaning of political pipes in the 19th century). Knasterkopf 14:49-53.

Standke, Bernd

1997 Zur Tonpfeifenbäckerei im sächsischen Grimma (On the clay-pipe production in Saxon Grimma). Knasterkopf 10:1-51.

Standke, Gerda

2003 Tonpfeifen-Pfeifenton: Zur geologischen Geschichte des Rohstoffes (Clay pipes - pipe clay: Toward the geological history of the raw material). Knasterkopf 16:99-104.

Stephan, Hans-Georg

1995 Großalmerode: Ein europäisches Zentrum der Herstellung von technischer Keramik. Teil II: Technische und Baukeramik, Tonpfeifen, Knicker, Steingut (Großalmerode: A European center of the production of technical ceramics. Part II: Technical and building-construction ceramics, clay pipes, marbles, creamware). Glas- und Keramikmuseum, Großalmerode, Germany.

Stephan, Hans-Georg

2012 Ein Plädoyer für die Archäologie der Neuzeit: Eindrücke und Erfahrungen aus vier Jahrzehnten Arbeit in Nordrhein-Westfalen, Niedersachsen, Hessen, Thüringen, Sachsen-Anhalt und Sachsen (A plea for the archaeology of the modern period: Impressions and experiences from four decades of work in North Rhine-Westphalia, Lower Saxony, Hesse, Thuringia, Saxony Anhalt and Saxony). In Neue Zeiten: Stand und Perspektiven der Neuzeitarchäologie in Norddeutschland, Ulrich Müller, editor, pp. 273347. Habelt Verlag, Bonn, Germany.

Teichner, Felix

1998 Tonpfeifenbäcker in Berlin und Brandenburg: Bodenfunde von der Westkurtine der Spandauer Zitadelle (Clay-pipe makers in Berlin and Brandenburg: Excavated finds from the west curtain wall of the Spandau citadel). EthnographischArchäologische Zeitschrift 39:353-365. 
Theune, Claudia

2016 Archäologie an Tatorten des 20. Jahrhunderts (Archaeology at crime scenes of the 20th century), 2nd revised edition. Theiss Verlag, Stuttgart, Germany.

van der Meulen, Jan

2003 Goudse pijpenmakers en hun merken (Gouda pipe makers and their marks). Labor Vincit, Leiden, the Netherlands.

Walker, Iain C.

1967 Statistical Methods for Dating Clay Pipe Fragments. Post-Medieval Archaeology 1:91-101.
Walker, Iain C.

1970 Dating Clay Pipes from the Galphin Trading Post in Silver Bluff, South Carolina. Florida Anthropologist 23(4):159-162.

Wilts, Andreas

1996 Starker Tobak: Tabakgenuß und Tabakverbote in Konstanz und am Bodensee im 17. und 18 Jahrhundert (Strong stuff: Tobacco consumption and tobacco bans in Constance and on Lake Constance in the 17 th and 18 th centuries). Knasterkopf 8:45-50. 